\title{
Factors Affecting the Financing of Small and Medium Sized Real Estate Enterprises
}

\author{
Chang Zhang ${ }^{1,2}$ \\ ${ }^{1}$ School of economics and management, Xianyang Normal University, Xianyang, 712000, Shaanxi, \\ China \\ ${ }^{2}$ School of Public Administration, Northwest University, Xi'an, 710119, Shaanxi, China
}

\begin{abstract}
:
Under the role of private capital in financial services, can shadow banking play a positive role in the development of small and medium-sized real estate enterprises. Based on this thinking, this paper puts forward the role of shadow banking in the financing process of small and medium-sized real estate enterprises. Through the analysis and demonstration of AHP model, it quantifies the key factors of small and medium-sized real estate enterprises in the four financing schemes of trust, REITs, financing guarantee and private financial system, and extracts the key factors as the comparison items. The financing suggestions for small and medium-sized real estate enterprises mainly focus on making financing decisions according to the consistency of their own financing objectives and enterprise life cycle, and under the guidance of relevant policies and measures of the State Council and other countries, timely make financing plans based on the principle of low financing cost, so as to realize the sustainable development of small and medium-sized enterprises.
\end{abstract}

Keywords: Shadow banking, Financing decision, Analytic hierarchy process.

\section{INTRODUCTION}

The characteristics of the real estate industry are easily affected by capital problems. How to solve the sustainable capital supply chain is an important factor for the development of real estate enterprises. For small and medium-sized real estate enterprises, due to their own objectivity defects, their capital supply chain is weak, and vulnerable to the impact of national policies, land prices and enterprise management problems; On the other hand, due to the lack of brand effect, small and medium-sized real estate enterprises cannot attract more and better investment projects, so it is difficult for them to operate sustainably; Finally, the preferential policies for small and medium-sized real estate enterprises and the higher financing costs of the national policies hinder the progress of small and medium-sized real estate enterprises. However, the existence of small and medium-sized real estate enterprises, to a certain extent, inhibits the industry monopoly formed by large real estate enterprises, and promotes the 
diversion of real estate project development and social employment. In the real estate industry, the healthy competition of the real estate industry at the level of composition, in line with local characteristics and not in favor of the bubble development of housing prices, explores the value and significance of small and medium-sized real estate enterprises from the perspective of low financing cost and financing decisions in line with the development of enterprises.

Due to the complexity, fragility and difficulty in supervision of the scale of shadow banking system, it is generally believed that there are systematic risks in its development and the potential for financial crisis. However, at the same time, the development of shadow banking not only replaces some services of traditional banks, but also forms a situation of financial market competition and cooperation with traditional banking and financial institutions, Promote the improvement of the whole financial structure system.

However, compared with developed economies, shadow banking system in China is not mature. China is still a banking dominated financial structure system. The non bank financial institutions represented by shadow banks are not developed enough, the items of financial market are relatively single, the competitiveness of financial system is relatively weak, and the financial supervision system needs further reform and improvement.

Therefore, we should understand the development of China's shadow banking system, analyze its uniqueness and effective functions, explore its potential financial value's impact and help on the financing of small and medium-sized real estate enterprises, and put forward scientific and reasonable supervision system and development oriented suggestions and opinions in a forward-looking and flexible way, so as to guide the better development of China's small and medium-sized real estate enterprises, It is of great theoretical and practical significance to improve the establishment of China's financial structure system.

\section{ANALYSIS OF THE CURRENT SITUATION OF FINANCING OF SHADOW BANK AND SMALL AND MEDIUM-SIZED REAL ESTATE ENTERPRISES IN CHINA}

\subsection{The Development Status of Shadow Banking in China}

Compared with mature financial system countries, China is still the financial structure system dominated by banks. Non bank finance is not developed enough, and indirect financing is still the main one, and the scale of direct financing is relatively small. However, since 2010, the people's Bank of China has incorporated the "scale of social financing" into the financial statistical index system to monitor the changes in the scale and structure of social financing. At this time, there are not only broad and narrow differences in the cognition 
of shadow banks. From the total social financing scale of 12.83 trillion yuan in 2017, RMB loan has accounted for $58.3 \%$ of the total amount. It can be seen that RMB loan here is a broader definition of shadow banking system, the financing scale represented by shadow bank has accounted for the total social financing half of it.

In 2017, the scale of China's shadow banking was 65.6 trillion yuan, with shadow banking assets accounting for 79.3\% of China's GDP, down 7.4\% compared with 2016. Although shadow banking has become an important object of financial supervision since 2017, it still plays an important role in financing the formal financial system [1]. Although compared with the direct financing scale of developed economies, China is still in the initial stage, but the rising proportion, the rapid development of non bank financial institutions, the expansion of Bank off balance sheet business and other factors have obvious substitution effect on bank loans, and have an important impact on the current changes in China's financial structure and the effect of monetary policy macro-control.

2.2 Financing Environment of Small and Medium Sized Real Estate Enterprises in China

The notice on promoting the sustained and healthy development of the real estate market issued by China is referred to as document No. 18. The real estate industry is clearly regarded as one of the pillar industries, which also indicates that the Chinese government has begun to implement macro-control policies for the real estate industry. In the eight years from the end of 2003 to 2012, China's policies have made a total of 13 adjustments to the housing loan interest rate, the deposit and loan base interest rate and the RMB deposit reserve ratio of deposit financial institutions. By 2020, the regulatory measures will reach the peak. Due to the outbreak of the global financial crisis, the real estate industry will continue to heat up, the potential risk of global economic turbulence will increase, and the government's macro policies will be adjusted accordingly.

In 2017, shadow banking is the focus of supervision and regulation. The central government takes "stabilizing house prices, land prices and expectations" as the long-term control goal of real estate, and keeps the main tone of "real estate without speculation and increasing housing supply". In the process of asset securitization promoting the transfer of capital value, the state has also put forward new requirements for the financing audit means of real estate enterprises, further enhancing the functional services of credit increase and insurance, not only from the aspects of the number of residents' house purchase restrictions and loan restrictions, but also for real estate enterprises, The securitization of real estate mortgage and credit risk make more financial supervision. From the changes of the macro-control means of the Chinese government to the micro level of the real estate financial market, there are some problems, such as the imperfect system of the real estate market, the monopoly of the scale of real estate enterprises, and the single financing 
channel of the real estate financial market.

From the main business of shadow banking, the transfer of credit assets and the securitization of credit assets of trust companies and securities companies are the priority choice of real estate financial assets channels. In the first half of 2019, the national real estate development investment totaled 13219.4 billion yuan, of which the investment scale of residential category reached 9.771 billion yuan, an increase of 13.9\%; The scale of financing through trust channels is about RMB 242 billion, an increase of $9.9 \%$ compared with 2018; This shows that the amount of funds needed for real estate development is huge. The proportion of the total investment in real estate development in the total investment in fixed assets of the whole society remains relatively stable, which shows that there is great potential for the amount of funds provided by the development of real estate enterprises, so it is necessary to explore the financing diversification of real estate enterprises.

By 2019, the average asset liability ratio of listed real estate enterprises has reached nearly $92.5 \%$. The average asset liability ratio increased by 3.04 percentage points to $68.09 \%$; the average net debt ratio increased by 2.65 percentage points to $92.52 \%$. These data show that the survival of real estate enterprises does not mean that only small and medium-sized real estate enterprises have financing difficulties. Similarly, listed real estate enterprises are still facing capital intensive demand and the need to expand financing channels.

China's real estate market is still in effective demand. The demand we are talking about here should consider more effective demand. Effective supply reflected effective supply can avoid unnecessary bubbles, so as to avoid rising prices and asymmetric information in the real estate market. Objective analysis of effective demand is helpful for the government to adopt appropriate policy measures to intervene in the real estate market and assist real estate enterprises to explore new financing channels.

2.3 Analysis on the Financing Limitations of Small and Medium Sized Real Estate Enterprises in China

Under the guidance of financial inhibition theory, this paper further considers the influence of financial inhibition effect on the financing decision of small and medium-sized real estate enterprises under the existing financial system, especially in the game between the state and the real economy. This is an important reason that the financial system of China has seriously affected the development of real economy. Since the beginning of 2010, the actions taken by the state and the CBRC have increased the difficulty of enterprises obtaining loans from banks. This series of measures, to control the development of the real estate industry as the purpose, in fact, to small and medium-sized real estate enterprises as the object of this kind of capital intensive industry management brings many obstacles. 
In financial assets activities, enterprises are faced with the dual principal-agent relationship of financial institutions, enterprises, banks and investors. The inevitable information asymmetry and the efficiency of assets also increase the cost of enterprise financing. Banks and financial institutions should not only fully understand the repayment ability and credit risk of the enterprise, but also should not negate the whole process of setting a high threshold to meet the financing needs of entrepreneurs. In this process, banks need to pass more effective system audit, fully eliminate the problem of information asymmetry in the process of enterprise financing, improve the efficiency of information collection, and will not bring additional financing costs to enterprises. At the same time, in order to control the risk, banks need to implement credit rationing, that is to limit some people can not get loans to promote competition among borrowers, in order to achieve the purpose of preferential lending [2]. In view of the actual demand of enterprises for capital, banks as the main means of credit can not help small and medium-sized real estate enterprises to achieve better financing objectives and business needs.

The main challenges of real estate enterprises in China are as follows: the close relationship between macro policies and the real estate market, the relatively unstable market environment in which real estate enterprises are located The traditional bank loan mechanism, which is sensitive to the influence of national policies, can not meet the diversity and instability of real estate enterprises' demand in the long run [3]. In the 2020: China financial non-performing assets market survey report issued by Orient Asset Management Company, according to the industry classification, non-performing loans mainly focus on manufacturing, construction, personal loans and other industries, with a scale ratio of 1 times higher than that of the previous year; The NPL ratio is at least 2 percentage points, which all promote the trend of the increase of non-performing loans, which forces banks to restrict loans to real estate enterprises.

\section{AN EMPIRICAL ANALYSIS OF THE IMPACT OF SHADOW BANKING ON THE FINANCING OF SMALL AND MEDIUM SIZED REAL ESTATE ENTERPRISES}

\subsection{Establishment of Research Methods}

This paper mainly studies how to make China's financial market form a competitive mode, so as to facilitate the financing of small and medium-sized real estate enterprises in China and form the sustainable development of the real estate industry. First of all, SWOT is used to analyze the internal and external environment of small and medium-sized real estate enterprises, and the advantages, disadvantages, opportunities and potential threats of small and medium-sized real estate enterprises are analyzed. These qualitative descriptions can only be theoretical. Then, this paper constructs the influence relationship between shadow banking and small and medium-sized real estate enterprises by establishing an 
analytic hierarchy process model, This paper selects the factors from SWOT analysis as the criterion layer of the model, three financing methods in the shadow banking system as the target layer, collects expert opinions through Delphi method, calculates the judgment matrix, and obtains the quantitative relationship between the latter two.

The macro problem is decomposed into micro individual factors, and these factors are grouped according to the interrelated relationship to form an orderly hierarchical structure. The AHP model is established to weigh the proportion of influencing factors, and then the judgment of experts is integrated to determine the priority of the relative importance of various factors.

\subsection{Using AHP to Improve the Application of SWOT Model}

\subsubsection{Hierarchical model for selecting key environmental factors}

Based on the traditional SWOT analysis model, this paper analyzes the factors that affect the financing of small and medium-sized real estate enterprises from four aspects: the advantages of small and medium-sized real estate enterprises (S), the special objective restrictions of small and medium-sized real estate enterprises $(\mathrm{W})$, the policy and innovation potential of small and medium-sized real estate enterprises $(\mathrm{O})$, and the macro and micro institutional changes faced by enterprises $(T)$. This paper extracts the key environmental factors according to the SWOT analysis, establishes the AHP model, quantifies the optimal strategy that the enterprise can choose by analyzing the factors that affect the financing cost of small and medium-sized real estate enterprises, so as to obtain the feasibility of small and medium-sized real estate enterprises and the optimal financing method. 


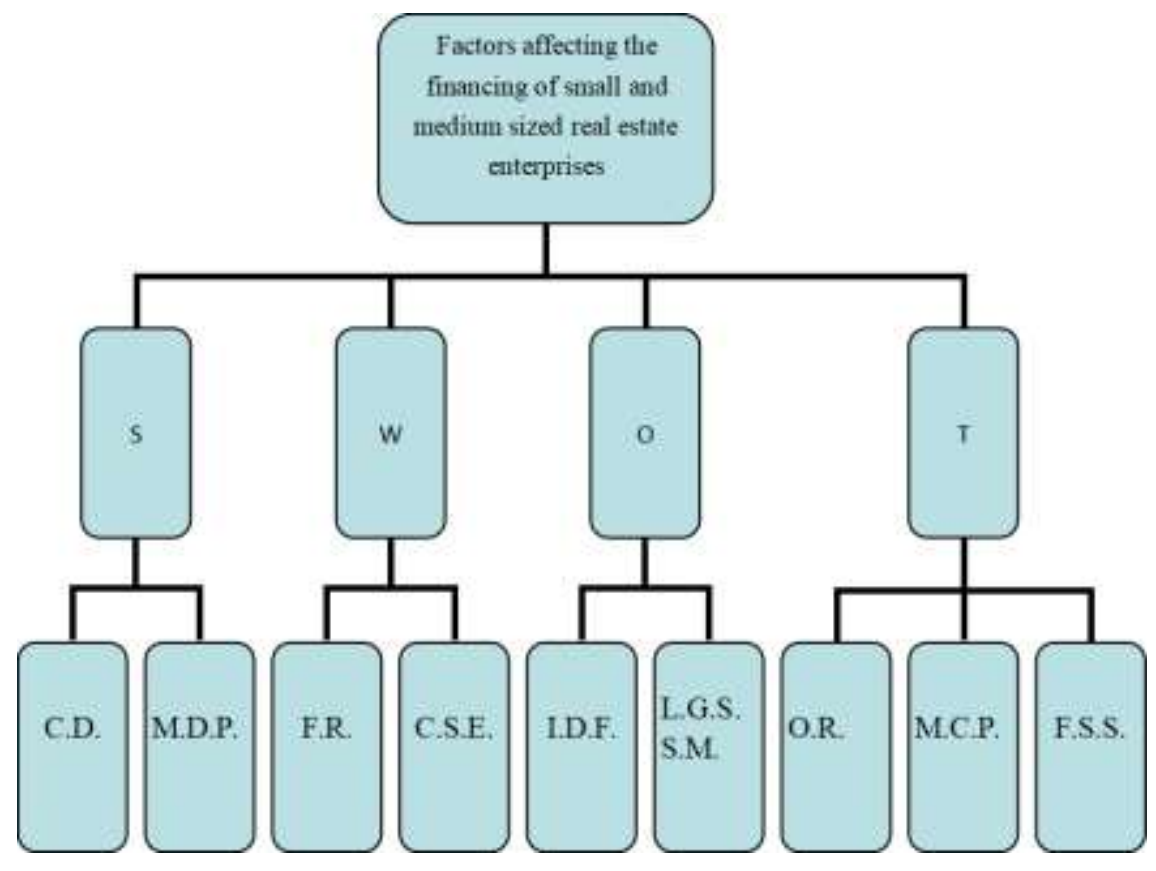

Fig 1: key environmental factors affecting the financing of small and medium-sized real estate enterprises

3.2.2 A hierarchical model for allocating financing indexes of small and medium sized real estate enterprises

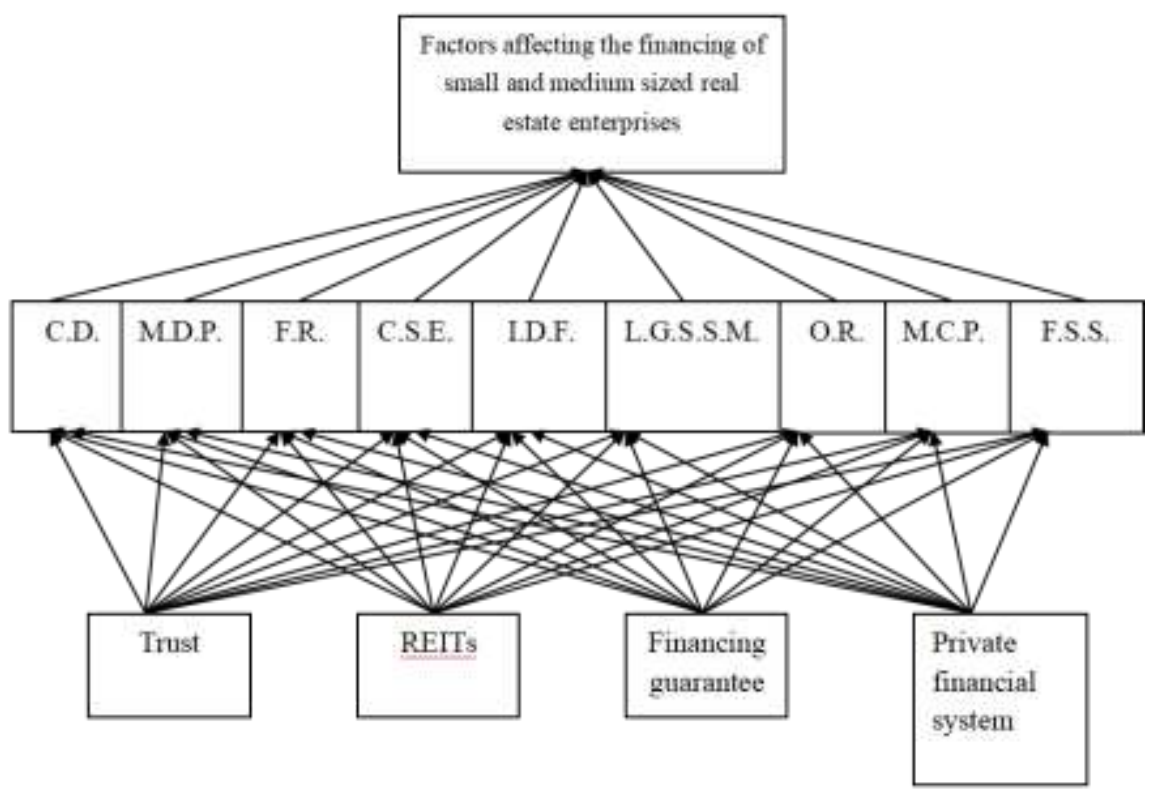

Fig 2: analytic hierarchy process model of financing factors of small and medium-sized real estate enterprises 


\author{
Abbreviations in Figures 1, 2: \\ CD: capital demand \\ M.D.P.: Market development potential \\ F.R.: Financing risk \\ C.S.E.: Competitive strength of enterprises \\ I.D.F.: Innovation of direct financing \\ L.G.S.S.M.: Local government's support for small and medium sized real estate \\ O.R.: Over reliance on indirect financing \\ M.C.P.: Macro control policy constraints \\ F.S.S.: The financing supervision system is not perfect
} enterprises

The effect of shadow bank on financing cost promotion and inhibition of small and medium-sized real estate enterprises is mainly reflected in: through trust, REITs, financing guarantee and non bank financial institutions and ways in the non-bank financial system, the shadow bank chooses the optimal financing mode, and uses AHP to take "trust, REITs, financing guarantee and private financial system" as the scheme layer, The criterion layer is the key environmental factor of SWOT judged by many experts. Through qualitative and quantitative analysis, the weight of each way in the scheme layer is obtained, and the influence degree on financing cost of small and medium-sized real estate enterprises is quantified.

\title{
3.2.3 Comparison and judgment matrix
}

The idea of analytic hierarchy process is to compare the elements in three or four layers and establish a judgment matrix, that is, to compare the relative importance of factors at a certain level. Let $\mathrm{n}$ factors associated with the upper factor $\mathrm{Z}$ be, for $x_{1}, x_{2}, \ldots, x_{n}$, while to $\mathrm{i}, \mathrm{j}=1,2, \cdots, \mathrm{n}$, use $a_{i j}$ to express $x_{i}$ and $x_{j}$ of the influence with respect to $\mathrm{Z}$, then a series of judgment matrices for pairwise comparison of $\mathrm{N}$ factors with respect to $\mathrm{Z}$ are obtained,

$$
A=\left[\begin{array}{cccc}
a_{11} & a_{12} & \ldots & a_{1 n} \\
a_{21} & a_{22} & \ldots & a_{2 n} \\
\ldots & \ldots & \ldots & \ldots \\
a_{n 1} & a_{n 2} & \ldots & a_{n n}
\end{array}\right]
$$

In the analytic hierarchy process, 9 scale method is generally used, that is, 17 numbers from 1 to 9 and their reciprocal are used as the scale to determine the $a_{i j}$ value. 
TABLE 1 Meaning of $1 \sim 9$ scale method

\begin{tabular}{|l|c|c|c|c|c|}
\hline MEANING & $x_{i} x_{j}$ & $x_{i} x_{j}$ & $x_{i} x_{j}$ & $x_{i} x_{j}$ & $x_{i} x_{j}$ \\
\hline \multirow{2}{*}{$a_{i j}$} & 1 & 3 & 5 & 7 & 9 \\
\cline { 2 - 7 } & 2 & 4 & 6 & 8 & \\
\hline
\end{tabular}

According to the analytic hierarchy process (AHP) structure model of financing factors of small and medium-sized real estate enterprises in Figure 2, we designed a questionnaire about financing factors of small and medium-sized real estate enterprises. We mainly employed experts and used the expert method to conduct the survey. The questionnaire was distributed to 10 experts, and the importance of each factor index was compared by using the "1 $~ 9$ scale method" in Table 1, after repeated consultation and statistics, the original data of this paper is obtained. By taking the average and variance of the survey results, eliminating individual invalid results and other statistical processing, 10 judgment matrices are constructed, which are 1 judgment matrix of scheme layer B for target layer a, and 9 judgment matrices of scheme layer $\mathrm{C}$ for criterion layer $\mathrm{B}$.

3.2.4 Hierarchical single ranking and consistency test of influencing factors

(1) Theoretical process of calculation

Next, according to the method of operation research AHP, the comparative judgment matrix is constructed to calculate the relative ranking weights of B-layer elements for target layer and C-layer elements for B-layer elements, and the consistency test is made. The specific steps are as follows:

A. Calculate the product Mi of elements in each row of the judgment matrix

$$
M_{i}=\prod_{j=i}^{n} a_{i j}, \mathrm{i}=1,2,3 \ldots \mathrm{n} ; \mathrm{N} \text { is the order of the matrix }
$$

B. Calculating the $\mathrm{n}$-th root of Mi

$$
\overline{w_{i}}=\sqrt[n]{M_{i}}, \mathrm{i}=1,2,3 \ldots \mathrm{n}
$$

C. The data $\bar{w}_{i}$ were normalized 


$$
W=\left(w_{1}, w_{2}, w_{3}, \ldots \ldots . ., w_{n}\right)^{T}
$$

D. Calculating the maximum eigenvalue of judgment matrix $\lambda_{\max }$

$$
\lambda_{\mathrm{max}}=\frac{1}{n} \sum_{i=1}^{\mathrm{n}} \frac{(\boldsymbol{A} \cdot \boldsymbol{W})_{i}}{w_{i}},(\mathrm{AW})_{\mathrm{i}} \text { is the I-th element of vector aw }
$$

E. Consistency test of judgment matrix

Consistency index:

$$
\text { C.I. }=\frac{\lambda_{\mathrm{m} \mathrm{a}}-n}{n-1}
$$

Consistency ratio:

$$
\text { C.R. }=\frac{\text { C.I. }}{R . I .}
$$

R. I. is the average random consistency index, which can be obtained by looking up the table, as shown in Table 2. According to the value of consistency ratio C.R., the consistency of comparison judgment matrix can be tested. When C.R. $<0.1$, it is considered that the consistency of the judgment matrix is acceptable. Otherwise, it is necessary to revise the pairwise comparison judgment value of the matrix and recalculate the relative weight vector W.

TABLE 2 Values of R.I. in different dimensions

\begin{tabular}{|l|l|l|l|l|l|l|l|l|l|l|}
\hline $\mathbf{N}$ & 1 & 2 & 3 & 4 & 5 & 6 & 7 & 8 & 9 & 10 \\
\hline $\mathbf{R I}$ & 0 & 0 & 0.58 & 0.90 & 1.12 & 1.24 & 1.32 & 1.41 & 1.45 & 1.49 \\
\hline
\end{tabular}

(2) According to the calculation result statistics of judgment matrix A, B1, B2, B3, B4, B5, B6, B7, B8, B9, as shown in Table 3.

For the judgment matrix $\mathrm{A} \sim \mathrm{B} 9$, the order of the matrix is 9 and 4 respectively.

$$
\omega^{(2)}=(0.0297,0.0348,0.0968,0.0626,0.1488,0.1158,0.0421,0.2198,0.2496)^{T}
$$


The C.R. < 0.1 of 10 matrices are calculated by formula (5) - (7), which shows that all judgment matrices meet the requirements of satisfactory consistency.

TABLE 3 Statistical results of judgment matrix

\begin{tabular}{|l|l|l|l|l|l|}
\hline $\begin{array}{l}\text { JUDGMENT } \\
\text { MATRIX }\end{array}$ & ORDER & RELATIVE SORTING WEIGHT & C.I. & C.R. & UNIFORMITY \\
\hline A & 9 & $\begin{array}{l}\boldsymbol{W}_{\boldsymbol{I}}^{(2)}=(0.0297,0.0348,0.0968,0.0626,0.148 \\
8,0.1158,0.0421,0.2198,0.2496)^{\mathrm{T}}\end{array}$ & 0.0984 & 0.0679 & accord with \\
\hline B1 & 4 & $\boldsymbol{W}_{\boldsymbol{I}}^{(\mathbf{3})}=(0.2415,0.5744,0.0749,0.1091)^{\mathrm{T}}$ & 0.0824 & 0.0916 & accord with \\
\hline B2 & 4 & $\boldsymbol{W}_{\mathbf{2}}^{(\mathbf{3})}=(0.0611,0.5736,0.1137,0.2516)^{\mathrm{T}}$ & 0.0596 & 0.0662 & accord with \\
\hline B3 & 4 & $\boldsymbol{W}_{\mathbf{3}}^{(\mathbf{3})}=(0.2334,0.5871,0.0609,0.1186)^{\mathrm{T}}$ & 0.0768 & 0.0853 & accord with \\
\hline B4 & 4 & $\boldsymbol{W}_{\mathbf{4}}^{(\mathbf{3})}=(0.2394,0.5695,0.0625,0.1286)^{\mathrm{T}}$ & 0.0788 & 0.0876 & accord with \\
\hline B5 & 4 & $\boldsymbol{W}_{5}^{(\mathbf{3})}=(0.0617,0.5534,0.1118,0.2731)^{\mathrm{T}}$ & 0.0785 & 0.0872 & accord with \\
\hline B6 & 4 & $\boldsymbol{W}_{\mathbf{6}}^{(\mathbf{3})}=(0.0908,0.6069,0.0648,0.2375)^{\mathrm{T}}$ & 0.0858 & 0.0953 & accord with \\
\hline B7 & 4 & $\boldsymbol{W}_{\mathbf{7}}^{(\mathbf{3})}=(0.2702,0.5318,0.0760,0.1221)^{\mathrm{T}}$ & 0.0428 & 0.0476 & accord with \\
\hline B8 & 4 & $\boldsymbol{W}_{\boldsymbol{8}}^{(\mathbf{3})}=(0.2873,0.5507,0.0909,0.0711)^{\mathrm{T}}$ & 0.0765 & 0.0850 & accord with \\
\hline B9 & 4 & $\boldsymbol{W}_{\mathbf{9}}^{(\mathbf{3})}=(0.0678,0.5645,0.1587,0.2089)^{\mathrm{T}}$ & 0.0850 & 0.0944 & accord with \\
\hline
\end{tabular}

3.2.5 The total ranking and overall consistency test of each element of scheme layer C to target layer a

According to the analytic hierarchy process (AHP) theory of operational research, from the relative weights w (2), W1 (3), W2 (3), W3 (3), W4 (3), W5 (3), W6 (3), W7 (3), W8 (3), w9 (3) under the single criterion calculated above for the elements of the upper layer, as well as the consistency test index under the single criterion, the composite weight of each element of scheme layer $\mathrm{C}$ relative to target layer a can be calculated:

$$
\begin{aligned}
W(3)=(W 1(3), W 2(3), & W 3(3), W 4(3), W 5(3), W 6(3), W 7(3), W 8(3), W 9(3)) * W(2)= \\
(0.1580,0.5665,0.1029,0.1726) T & (9)
\end{aligned}
$$

The overall consistency index of $\mathrm{C}$ layer elements to target layer a is as follows:

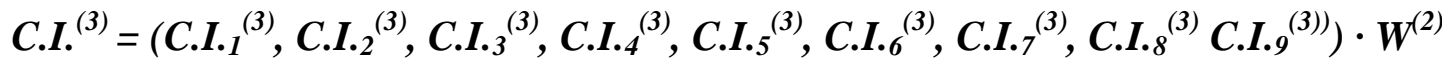

$$
\begin{aligned}
& =0.0761
\end{aligned}
$$




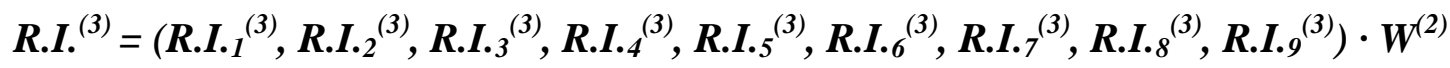

$$
\begin{aligned}
& =0.9
\end{aligned}
$$

The overall consistency ratio is as follows:

$$
\text { C.R. }{ }^{(3)}=\text { C.I. }{ }^{(3)} / \text { R.I. }^{(3)}=0.0846<1 .
$$

This shows that the judgment results of hierarchical structure in the scheme layer $\mathrm{C}$ and the overall relative ranking weight W (3) have overall satisfactory consistency.

The weight of scheme layer $\mathrm{C}$ to target layer a is $\mathrm{w}(3)=(0.1580,0.5665,0.1029,0.1726)$ $\mathrm{t}$, which shows that in considering the factors affecting the financing cost of small and medium-sized real estate enterprises, "REITs" accounts for the largest proportion, about $57 \%$, followed by "private financial system", about 17\%, followed by "trust", about 16\%, and finally financing guarantee, about $10 \%$.

3.3 Analysis on the influencing factors of financing decision of small and medium sized real estate enterprises

\subsubsection{Quantitative analysis of the impact of trust mode on the results}

The weights of trust and financing guarantee are $15.8 \%$ and $10.3 \%$ respectively. As a part of the shadow banking system, the effectiveness of trust and financing guarantee has an impact on the financing decisions of small and medium-sized real estate enterprises. Because of the development of REITs, compared with trust financing, it has the advantage of being suitable for real estate enterprises, and the object of financing guarantee is also for small and medium-sized enterprises which are difficult to obtain funds. What is different from the other three is that when carrying out financing guarantee, the premise of financing guarantee business is to provide guarantee for the guaranteed with its own reputation and capital strength, its potential risk is huge. If we can effectively improve the ability to resist risks, constantly improve the risk supervision system, and at the same time, the government implements strict industry management measures.

\subsubsection{Quantitative analysis of REITs mode influence results}

The results show that trust and REITs account for $62 \%$ of the total financing impact, indicating that trust and REITs are relatively effective financing methods. At present, China's small and medium-sized real estate enterprises are small, the internal management technology is not advanced enough, and the core competitiveness of enterprises is insufficient. REITs' investment in real estate enterprises belongs to equity investment, 
which can reduce the debt burden of enterprises. The improvement of equity structure will play an external supervision role in the operation of real estate enterprises and reduce the financing cost of enterprises, at the same time, REITs can help to optimize the internal structure of enterprises. Driven by the profit of investment projects, REITs can promote mergers and acquisitions of enterprises and realize the optimal allocation of resources [4]. As for the role of REITs in solving the financing problems of small and medium-sized real estate enterprises, it needs further correct guidance and supervision of our government, to provide a long-term value-added environment for REITs, and at the same time to give our real estate enterprises a long-term return on investment.

\subsubsection{Quantitative analysis of the impact of private financing}

As a shadow banking system, private lending is inferior to REITs, but also higher than financing guarantee. As a solution to the financing problems of small and medium-sized real estate enterprises, private lending also plays an important role in the financing process of small and medium-sized real estate enterprises. In view of the scale and strength of small and medium-sized real estate enterprises, the private financial system is more in line with the financing needs of small and medium-sized enterprises, promoting cooperation among enterprises and solving the problem of high financing cost caused by information asymmetry in the financing process. On the one hand, the competition between private financial system and bank financial institutions also promotes the reform and innovation of China's financial market, which is conducive to improving financial efficiency [5]. On the other hand, the private financial system is still inseparable from strict supervision and correct guidance, so as to effectively avoid its financial instability and risk, and provide sustainable financing services for small and medium-sized real estate enterprises.

\section{CONCLUSION}

The rise of shadow banking system is the symbol of the birth of complex financial system, which greatly improves and expands the financial function. It is usually more efficient than the traditional banking system in terms of loans, credit services and transaction costs. It can provide non-traditional sources of capital and liquidity for individual investors, financial institutions, non-financial enterprises and even the government, meet the investment and financing needs of increasingly diverse households, and work together with the traditional banking system to promote the expansion and upgrading of financial functions to a higher level [6]. In order to effectively improve the influence of China's shadow banking on the financing scheme of China's small and medium-sized real estate enterprises, this paper puts forward the following conclusions on the financing decision-making mode of China's small and medium-sized real estate enterprises:

First, among the current financing methods of shadow banking, REITs, private lending 
and financing guarantee, the development of REITs represents the function of financial innovation and broadening the financing channels of real estate enterprises. Simple REITs product design will not increase the additional burden of real estate enterprise financing; Information disclosure solves information asymmetry and reduces the credit problems of real estate enterprises and financial institutions; solving policy problems is the most fundamental principle, which can better start from reality and start the most fundamental financing problem of real estate enterprises.

Second, at present, China's REITs are in the pilot promotion stage, the cost of trust financing is gradually increasing, private lending needs more financial regulations, and the high risk is more likely to lead to a crisis for the survival of small and medium-sized real estate enterprises Financing guarantee needs the improvement of credit and guarantee qualification of small and medium-sized real estate enterprises, which makes the financing advantages of shadow banks to small and medium-sized real estate enterprises still need to be further explored and explore more financial functions, not only reflected in credit financing services and value preservation and value-added functions.

Third, at the macro level, while affirming the driving role of shadow banking in the financing of small and medium-sized real estate enterprises, the government and regulators should actively create a good institutional environment for the realization and development of its role, and flexibly adjust the administrative control scale of shadow banking; At the micro level, small and medium-sized real estate enterprises should strengthen competitiveness management and risk management under the principle of minimizing financing costs. While blindly seeking solutions to financing problems, small and medium-sized real estate enterprises should strengthen their own construction and improvement to avoid being eliminated in the new round of financial reform.

Fourth, China's shadow banking system has gradually reflected the functions of risk management and liquidity enhancement, strictly controlled the development of shadow banking from the regulatory level, diversified financing channels from the financial development level, and opened up more and more effective paths for the financing of small and medium-sized real estate enterprises.

\section{ACKNOWLEDGEMENT}

This work was supported in part by Analysis on the impact of shadow banking on the financing cost of small and medium-sized real estate enterprises in China under grant NO.XSYK17011.

\section{REFERENCE}

[1] Yang M (2011) Shadow banking: how deep is the water. Financial times, 1. 
[2] Wang JW, Huang Z (2013) On the basis, problems and regulation path of private lending in China. Journal of Chongqing University (SOCIAL SCIENCE EDITION) (1): 25-31.

[3] Sun H C, Tian P, Wang L F (2011) Network analytic hierarchy process and Decision Science. Beijing: National Defense Industry Press, 29.

[4] Zhang B J, Wang S Y, Wei Y J, Zhao X T (2021) Research on risk transmission channels and regulatory Countermeasures of shadow banking in China. Systems engineering theory and practice, 41 (1).

[5] Peng J G, He J (2008) On the connection between private finance and local small and medium sized financial institutions. Inner Mongolia Social Sciences, 3.

[6] Tang H J (2012) Shadow banking system: function, vulnerability and regulatory reform. Beijing: Intellectual Property Press, 203-204. 